
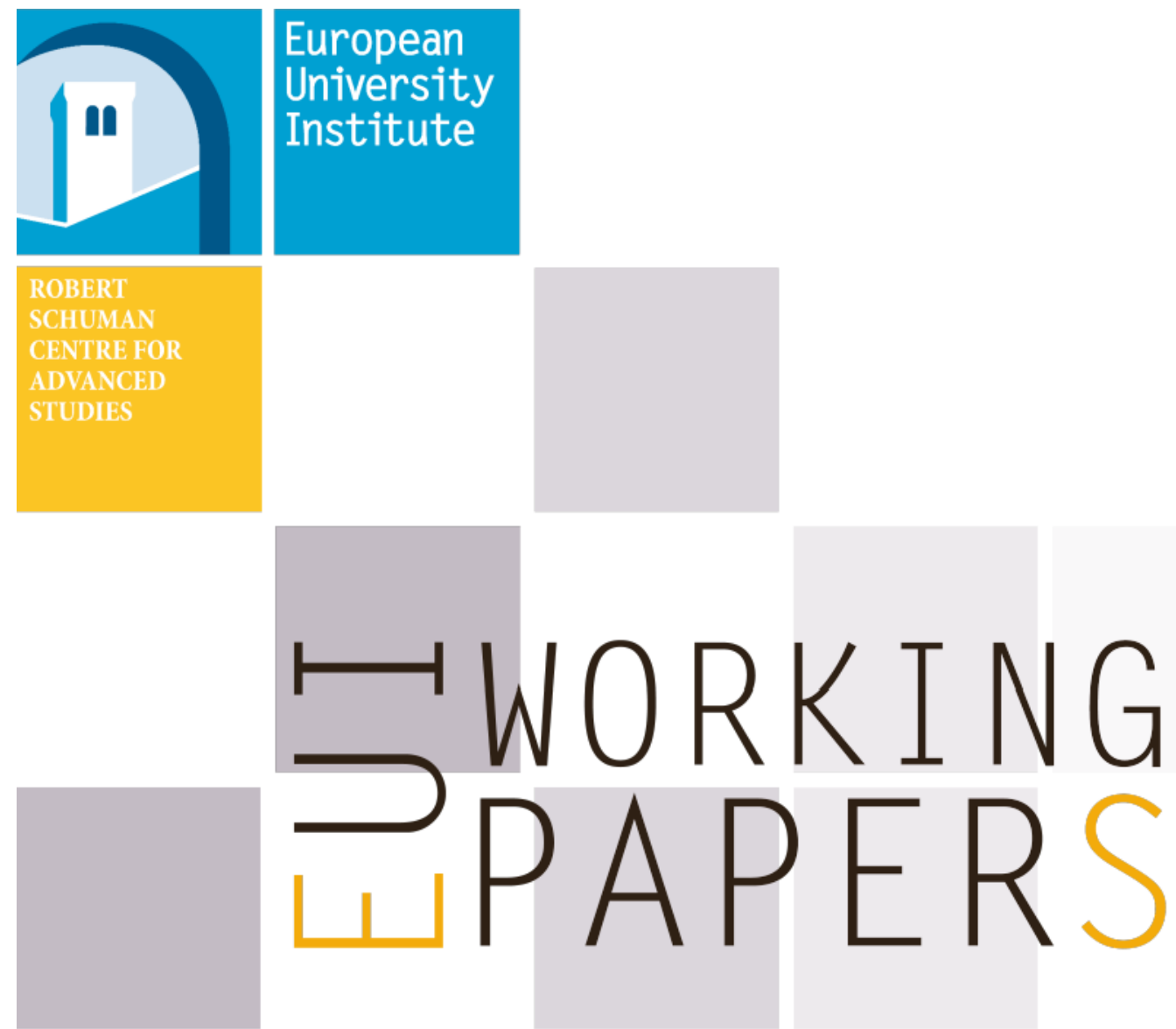

\title{
RSCAS 2017/64
}

Robert Schuman Centre for Advanced Studies Global Governance Programme-288

India - Solar Cells: Trade Rules, Climate Policy, and Sustainable Development Goals 

European University Institute

Robert Schuman Centre for Advanced Studies

Global Governance Programme

India - Solar Cells: Trade Rules, Climate Policy, and Sustainable Development Goals

Marianna Karttunen and Michael O. Moore

EUI Working Paper RSCAS 2017/64 
This text may be downloaded only for personal research purposes. Additional reproduction for other purposes, whether in hard copies or electronically, requires the consent of the author(s), editor(s). If cited or quoted, reference should be made to the full name of the author(s), editor(s), the title, the working paper, or other series, the year and the publisher.

ISSN 1028-3625

(C) Marianna Karttunen and Michael O. Moore, 2017

Printed in Italy, December 2017

European University Institute

Badia Fiesolana

I - 50014 San Domenico di Fiesole (FI)

Italy

www.eui.eu/RSCAS/Publications/

www.eui.eu

cadmus.eui.eu 


\section{Robert Schuman Centre for Advanced Studies}

The Robert Schuman Centre for Advanced Studies (RSCAS), created in 1992 and directed by Professor Brigid Laffan, aims to develop inter-disciplinary and comparative research and to promote work on the major issues facing the process of integration and European society.

The Centre is home to a large post-doctoral programme and hosts major research programmes and projects, and a range of working groups and ad hoc initiatives. The research agenda is organised around a set of core themes and is continuously evolving, reflecting the changing agenda of European integration and the expanding membership of the European Union.

Details of the research of the Centre can be found on:

http://www.eui.eu/RSCAS/Research/

Research publications take the form of Working Papers, Policy Papers, Policy Briefs, Distinguished Lectures, Research Project Reports and Books.

Most of these are also available on the RSCAS website:

http://www.eui.eu/RSCAS/Publications/

The EUI and the RSCAS are not responsible for the opinion expressed by the author(s).

\section{The Global Governance Programme at the EUI}

The Global Governance Programme is one of the flagship programmes of the Robert Schuman Centre for Advanced Studies at the European University Institute (EUI). It aims to: build a community of outstanding professors and scholars, produce high quality research and, engage with the world of practice through policy dialogue. At the Global Governance Programme, established and early career scholars research, write on and discuss, within and beyond academia, issues of global governance, focussing on four broad and interdisciplinary areas: European, Transnational and Global Governance; Global Economics; Europe in the World; and Cultural Pluralism.

The Programme also aims to contribute to the fostering of present and future generations of policy and decision makers through its unique executive training programme, the Academy of Global Governance, where theory and "real world" experience meet. At the Academy, executives, policy makers, diplomats, officials, private sector professionals and academics, have the opportunity to meet, share views and debate with leading academics, top-level officials, heads of international organisations and senior executives, on topical issues relating to governance.

For more information: http://globalgovernanceprogramme.eui.eu 



\begin{abstract}
India - Solar Cells is one of a growing number of WTO disputes that highlight the continuing tensions between climate change polices (and renewable energy manufacturing initiatives in particular) and established multilateral trading rules. The United States alleged that Indian policies discriminated against foreign solar cell suppliers operating in the Indian market. The Appellate Body broadly rejected India's arguments to justify the measure either under Article III.8 public procurement derogations or as a general exception under "short supply" and "compliance with laws and regulations" provision of Article XX of the GATT. We argue that the Appellate Body was correct both on legal and economic grounds. The case does highlight the continuing need for clarity about the allowed parameters for climate change policies within the multilateral trade system.
\end{abstract}

\title{
Keywords
}

Clean energy trade policy, solar energy, WTO general exceptions. 



\section{Introduction}

The WTO's Appellate Body (AB) India-Solar Cells ${ }^{1}$ report is seemingly a straightforward assessment of whether India could invoke government procurement derogations under Article III of the GATT to impose domestic content requirements (DCR) on inputs purchased by private companies that subsequently contracted to sell electricity to the Indian government. The United States alleged that these policies discriminated against foreign suppliers operating in India. The AB broadly rejected India's arguments under Article III as well as its appeals to exceptions under the GATT's Article XX "short supply" and "compliance with laws and regulations" provisions.

However, other issues also arise in this case that are more important to the broader international system. Perhaps most critically, India-Solar Cells is one of a growing number of WTO disputes to highlight continued economic and legal tensions between climate change polices (and renewable energy manufacturing initiatives in particular) and multilateral trading rules. This tension arises because the products at the heart of the dispute are photovoltaic solar cells and modules (PVCM).

Economically efficient and WTO consistent policy choices are quite complicated in this context given a number of possible "externalities." Pure free market outcomes are unlikely to deal with these problems. Yet the question remains: What are appropriate policies? The Indian government DCR provisions for PVCMs were undertaken with the explicit goals of: increasing renewable energy capacity for sustainable development; expanding electricity access to alleviate poverty; and fulfilling international climate change commitments. The dispute also highlights ongoing efforts around the world to use various public policy interventions to establish a strong presence in renewable energy manufacturing sectors; India is certainly not alone in intervening to help a domestic solar manufacturing industry. The policies also fit into India's long-standing efforts to promote domestic manufacturing. The essential policy question is whether banning imports of certain types of solar cells and panels as India did in this case is the best approach given this complicated matrix of policy goals.

The case also illustrates the difficulties surrounding WTO-legal policy options on climate change. This is the first time that general exceptions under Article XX (d) and (j) of the GATT have been assessed by the $\mathrm{AB}$ in the context of climate-relevant policies of a member government. While India's policies were considered discriminatory in the current case, the AB's response to India's claims hints about possible future uses of Article XX exceptions based on climate goals. In particular, the AB adopts a wider interpretation than in previous case law of Article XX (d) on compliance with laws and regulations not inconsistent with GATT, thus perhaps opening the way for future defenses on the basis of international environmental obligations.

India-Solar Cells specifically involves policies announced by the Indian government in 2010. The stated objective was to "establish India as a global leader in solar energy, by creating the policy conditions for its diffusion across the country as quickly as possible" ( $\$ 1.2$ of $\mathrm{AB}$ report). But the policy reflects longer standing broad ambitions in the context of the Indian government's 2008 National Action Plan on Climate Change to: a) "sustain rapid economic growth while dealing with the global threat of climate change;" while b) recognizing "the overriding priority of economic and social development and poverty eradication." (Government of India, 2008, 1).

The Obama Administration supported Indian's broad renewable energy objectives but argued that discriminatory policies can have a counterproductive effect for clean energy. The issue, according to the United States, was not the goal of the policy but the mechanisms used. The U.S. Trade Representative issued a public statement after the India-Solar Cells panel was launched, noting that:

1 India-Certain Measures Relating to Solar Cells and Solar Modules, WT/DS456/AB/R. 
"the United States strongly supports the rapid deployment of solar energy around the world, including with India. Unfortunately, India's discriminatory policies in its national solar program detract from that successful cooperation, raise the cost of clean energy, and undermine progress toward our shared objective." (USTR, 2013)

India-Solar Cells marks what may be a first step of a broader and continuing dispute between the United States and India on solar energy. Only a few days before the AB issued its final India - Solar Cells report, India initiated what may be a tit-for-tat dispute involving a number of U.S. state-level incentives that allegedly favored domestic over imported renewable energy sector firms (including solar module producers), including local content requirements. A WTO Panel was established on 21 March 2017 to examine these U.S. policies. ${ }^{2}$

International trade disputes involving solar power specifically, and renewable energy more generally, are becoming more common, often involving the same countries and similar products. There are also many antidumping, countervailing duty, and safeguard measures in the PVCM sector including: an Indian antidumping case on PVCMs brought against the United States, China, Malaysia, and Taiwan in 2012; Chinese antidumping and countervailing duty cases on a PVCM intermediate input brought against the United States in 2012; and a U.S. safeguard petition for PVCMs in 2017. There also have been cases targeting silicon metal, which is an upstream input used both for solar cells and semiconductors. ${ }^{3}$

India-Solar Panels is most closely related to Canada-Feed in Tariffs, which also involved domestic content requirements for renewable energy products. Charnovitz and Fischer (2015) provide an analysis of this case in which Canada was found in violation of the GATT and the Agreement on Trade Related Investment Measures (TRIMS). In the current case, India policies also were deemed inconsistent with its WTO obligations, and where applicable, the reasoning of Canada-Renewable Energy was used almost identically.

A notable difference between the two cases is the absence of arguments in India - Solar Cells based on the WTO Agreement on Subsidies and Countervailing Measures ("SCM Agreement"). This is surprising given that the United States had identified Articles 4, 7 and 30 of the SCM as a basis for its complaint in its initial consultation request. ${ }^{4}$ However, the United States did not raise these claims in its request for establishment of a Panel. ${ }^{5}$ Given the confidential nature of consultations, one may only speculate why the United States dropped this line of argumentation. It is likely that the AB report of Canada-Feed in Tariffs (issued after the request for consultations and before the establishment of the Panel) had an impact on the U.S. decision. Indeed, the AB's new analysis on the existence of a subsidy (particularly the need to establish the existence of a benefit) is more complex, thus potentially discouraging the United States from embarking on this route (Charnovitz and Fischer, 2015 and Rubini and Cosbey, 2017). More broadly, this may suggest an unwillingness by WTO Members to undertake claims under the SCM Agreement because of a fear of creating a precedence on green energy subsidies that could result in a wide range of counter-claims (Rubini, 2014).

The AB has avoided taking an explicit stance on renewable energy per se in these cases and instead has remained focused on the technicalities of the different arguments despite the need for clear disciplines on this subject. A myriad of requests for consultation raised in the past years concerning renewable energy may force the $\mathrm{AB}$ to take a clearer stance on renewable energy goods in the near future. ${ }^{6}$

\footnotetext{
2 United States - Certain Measures Relating to the Renewable Energy Sector, WT/DS510/2.

See Bown (2016) for a list of cases.

WT/DS456/1

5 WT/DS456/5

6 Examples include: Request for Consultations by the United States, China - Measures Concerning Wind Power Equipment WT/DS419/1; Request for Consultations by Argentina, European Union and Certain Member States - Certain
} 
The rest of the paper provides legal and economic perspectives on the AB India - Solar Cells report. Section 2 summarizes the Indian measure challenged by the U.S., the Panel ruling, arguments on appeal and the Appellate Body report. Section 3 includes an evaluation of the legal and economic issues surrounding the dispute with particular focus on the tension between trade and environmental considerations.

\section{Summary of Case and Arguments}

\subsection{Facts}

The Indian government launched the Jawaharlal Nehru National Solar Mission (NSM) in 2010. Under the NSM, the government concluded power purchase agreements (PPA) with private solar power developers (SPDs) and guaranteed to purchase electricity from them at a certain rate for a 25-year term. The Indian government then resold the purchased electricity to downstream distribution companies, which in turn sold electricity to final consumers. These agreements placed increasingly stringent DCRs for solar cells and modules as part of the PPAs. Only solar power generators selling to the Indian government under these agreements were subject to the DCRs.

The production chain for solar energy production and distribution has the following steps. Silicon metal is processed to form polysilicon ingots, which subsequently is transformed into wafers and then solar cells. These cells are then combined into a "solar module," which in turn typically is installed on a rooftop or large-scale industrial applications to produce electricity. This electricity is then distributed to final consumers. Consequently, the Indian DCRs were applied to only a particular part of the overall solar energy process.

Three types of photovoltaic technology are relevant in this discussion: 1) crystalline silicon (c-Si) cells, which is by far the most common type; 2) "thin film" cells, which are cheaper but less efficient than c-Si; and 3) "concentrator cells," which are used in conjunction with curved surfaces that focus sunlight.

The NSM domestic content requirements were phased in over time:

- Phase 1, Batch 1 (2010-2013): all SPDs using c-Si technologies must buy c-Si modules from Indian manufacturers; use of foreign c-Si cells and foreign thin-film modules or concentrator cells allowed;

- Phase 1, Batch 2 (2013-2017): all projects using c-Si technology must use c-Si cells and modules manufactured in India; use of domestic or foreign produced modules using thin-film modules or concentrator cells allowed;

- Phase II (2017-2022): all solar cells and modules must be made in India regardless of technology used.

The Indian government DCRs therefore were in the upstream part of the solar generation process. The DCRs vary over time with specificity, presumably aimed to allow Indian manufacturers to ramp up capacity in the different technologies with increasingly restrictive DCRs.

The United States, worried in particular that the DCRs would extend ultimately to thin film technologies that represent a majority of U.S. solar exports to India, launched a request for consultations under the WTO Dispute Settlement Mechanism on 6 February 2013. The United States argued that the DCR measures adopted under the NSM discriminated against foreign suppliers and thus violated the GATT, the TRIMs Agreement and the SCM Agreement. After bilateral consultations

\section{(Contd.)}

Measures On the Importation and Marketing of Biodiesel and Measures Supporting the Biodiesel Industry WT/DS459/1; Request for Consultations by China, European Union and Certain Member States - Certain Measures Affecting the Renewable Energy Generation Sector WT/DS452/1. 
failed to reach an understanding, a Panel was established on 23 May 2014. The Panel's report was issued on 24 February 2016. The Indian government subsequently filed an appeal on various aspects of the Panel's decision (discussed in more detail below). The Appellate Body circulated its report on 16 September 2016.

\subsection{Panel Ruling, Arguments in Appeal, and AB Ruling}

The Panel found that India had violated national treatment obligations of Article 2.1 of the TRIMS Agreement and Article III.4 of the GATT 1994. Furthermore, it rejected India's arguments that the DCR measures were covered by the government procurement derogation of Article III. 8 of the GATT ("Article III.8"), justified by general exceptions of short supply under Article XX (j) of the GATT ("Article XX (j)"), or needed to ensure compliance with laws and regulations under Article XX (d) of the GATT ("Article XX (d)"). India appealed the decision on the grounds that the Panel had erred in its interpretation of these GATT provisions.

\subsubsection{Art III.8 - Government Procurement Derogation from National Treatment}

India argued that its DCR measures were covered by the national treatment derogation provisions of Article III.8. To evaluate this argument, the Panel examined whether the discriminatory treatment existed between the products subject to discrimination (imported PVCMs) and products directly procured by the Indian government (solar electricity purchased under a PPA). Relying heavily on the AB's analysis in Canada - Renewable Energy, the Panel found that the DCR measures were not covered by the derogation because the Indian government purchases electricity whereas the DCR discrimination relates to solar cells and modules that are used to produce electricity. In essence, upstream inputs (PVCMs bought by private solar power generating firms) were not considered procured by the government (even indirectly) in its purchase of the downstream output (electricity).

India on appeal argued that the Panel had "mechanically" applied the Appellate Body's test of a competitive relationship developed in Canada - Renewable Energy and had not assessed all of India's arguments, most notably that PVCMs are "indistinguishable" from solar power generation.

The AB determined that the Panel was well in its rights not to consider arguments it deemed not pertinent for the ruling and was correct in its analysis concerning Article III.8. It reiterated its position in Canada-Feed in Tariff that the government procurement carve-out required that foreign product must be directly competitive with, or substitutable for, the procured product. The AB therefore dismissed India's argument about the necessity of examining whether PVCMs constituted necessary inputs for solar power generation and concluded that the character of "input" would only "inform" the determination of a competitive relationship.

\subsubsection{Article XX (j) - General Exception for Products in General or Local Short Supply}

India argued that if its Article III.8 derogation arguments were rejected, the measures could be justified instead under the general exception of Article XX (j) because they qualified as measures "essential to the acquisition or distribution of products in general or local short supply." India maintained that PVCMs were in "short supply" because India lacked sufficient domestic manufacturing capacity of these products. Moreover, India asserted that the DCR measures were essential to redress the short supply situation because of the policy goals of energy security and sustainable growth required indigenously manufactured solar cells and modules ( $\$ 5.46$ of AB Report).

The Panel rejected India's claims and found that the provisions of Article XX (j) did not entitle all Members to an equitable share in the international production of the relevant product but instead referred to "an equitable share of the international supply of the product." (Emphasis added.) Finally, the Panel considered that potential risks of import disruption was not the situation of short supply 
implied by Article XX (j) because the Article makes reference only to imminent risks of shortage. In its appeal, India claimed that the Panel had erred in making a restrictive interpretation of Article XX (j) and reiterated that "general or local short supply shortages" exist simply in the presence of low domestic manufacturing capacity.

This is the first time that Article XX (j) has been interpreted by the WTO DSM and therefore helped clarify the exceptions' scope. The AB recalled the two-step analysis applicable: 1) whether the measure is justified under a specific paragraph of Article XX; and 2) whether the measure is consistent with the chapeau of Article $\mathrm{XX}$, i.e. the measures do not reflect arbitrary or unjustifiable discrimination. For Article XX (j), the $A B$ specified that a measure needed first to be proven to be "designed to address the acquisition or distribution of products in general or local short supply" and second that they are "essential" to address the situation of short supply.

The AB confirmed the Panel's finding that India's lack of domestic manufacturing capacity was not sufficient to constitute product shortage and agreed that India merely identified potential disruptions to imports and failed to demonstrate that the SPDs had experienced any actual disruptions. Finally, the $\mathrm{AB}$ rejected India's claim that the objectives of energy security and sustainable growth make the DCR measures "essential" to the acquisition of solar cells and modules. Although these societal interests or values objectives can indeed inform the evaluation of the essential character of a measure, they do not provide evidence on the lack of supply.

\subsubsection{Article XX(d): General Exception for Necessary Compliance with Laws and Regulations}

India also maintained that the DCR measures were necessary to secure compliance with "laws and regulations" as understood by Article XX (d). India argued that the DCR measures ensure compliance with four different Indian policies and four international instruments including the Preamble of WTO Agreement, the United Nations Framework Convention on Climate Change (UNFCCC), the Rio Declaration on Environment and Development of 1992, and the United Nations General Assembly Resolution on "The Future We Want."

The Panel excluded the international instruments from the scope of "laws and regulations" as understood by Article XX (j) because they do not have "direct effect" in India. It further considered that the domestic instruments did not include the "existence of any legally enforceable rule" and instead were "hortatory, aspirational, declaratory, and at times solely descriptive." The Panel did find that a fourth Act invoked by India constituted a law for the purpose of Article XX (d), but did not consider that the DCR measures "secured compliance" (i.e. enforced obligations) under that particular act.

India claimed on appeal that the four domestic policy instruments were laws within the meaning of Article XX (d) because the Indian legal system comprised "both 'binding' laws, and policies and plans, that provide the "framework for executive action," and that the DCR measures secured compliance to these Indian measures. In addition, India maintained that the four international instruments had direct effect in India and thus required compliance measures to be taken by the executive branch.

The $\mathrm{AB}$ rejected these Indian claims and confirmed its previous case law that "laws and regulations" refer exclusively to rules that are officially integrated into the domestic legal system of a WTO Member ( $\$ 5.106$ of AB report). Nevertheless, it underlined the diversity of ways in which international obligations could form part of domestic legal systems. In addition, it listed criteria to identify whether measures fall under the scope of "laws and regulations" of Article XX (d), focusing more on the relevant instrument's formal characteristics than on the instrument's source. General statements in international agreements about the need to combat climate change clearly will not be sufficient alone to satisfy the $\mathrm{AB}$ without explicit domestic implementation of those objectives, but 
specific normative obligations resulting from international commitments could be, depending on each Members' legal system.

\subsubsection{An Appellate Body Member's Separate Opinion}

A rare separate opinion by one $\mathrm{AB}$ Member does not dispute the report's final outcome or reasoning but is nonetheless notable. Only six separate opinions have been made by AB Members since the WTO's founding in 1995 (See Lewis 2012, Flett 2010). This separate opinion also reflects the political tension surrounding the Unites States' opposition to Mr. Seung Wha Chang's reappointment as Appellate Body Member, who helped decide India-Solar Cells.

The United States had opposed Mr. Chang's reappointment and claimed he had been involved in cases where the WTO DSB had not confined itself strictly to securing a positive solution to a dispute. The United States noted that "...it is not the role of panels or the Appellate Body to 'make law' outside the context of resolving a dispute" (WTO, 2016, 3). The separate opinion acknowledges that the $\mathrm{AB}$ cannot offer interpretative guidance beyond the scope required for a particular dispute but notes the importance of making sufficiently precise recommendations and rulings to ensure disputes effective resolution to all Members' benefit. (\$5.161-162 of AB report). Mr. Chang made a similar point in his farewell speech from AB membership (Chang 2016, 2).

Mr. Chang's last case was India - Solar Cells heard before his AB retirement due to U.S. opposition to his reappointment. As noted throughout this paper, the AB was particularly cautious in this case to avoid questions going beyond the claims of the parties. The separate opinion suggests that Mr. Chang wished to reiterate the AB's commitment to remain within its mandate and functions and seized the opportunity to leave a record of his position within the corpus of WTO case law.

\section{Key Legal and Economic Issues}

We turn now to analyze whether the AB's reasoning was appropriate given the facts of the case, past precedent, and relevant economic trends.

\subsection{Solar Cells as Inputs}

A critical part of India's argument for an Article III.8 derogation was that the government was indirectly purchasing solar cells and modules when it directly contracted for electricity generated specifically by solar power. In essence, India argued that stipulations on the purchase of domestic inputs for government contractors was covered by Article III.8. The United States responded by proposing that solar cells and modules were not inputs since they are not consumed during the production of solar energy. The AB declined to rule on India's position on inputs since they reasoned that the finding of a non-competitive relationship between PVCM purchases and solar energy generation meant that a necessary initial criterion for a derogation was not met.

There are two issues for analysis here.

The first is a legal argument about whether the $\mathrm{AB}$ should have considered whether the PVCMs were indeed covered by the government procurement derogation as inputs of the solar energy purchased by the Indian government.

The effect of inputs in the national treatment obligation is important first because it is a key argument of India and because it may have important consequences for WTO Members future environmental policies.

Inputs are not explicitly mentioned by Article III and have not yet been defined by case law. Nevertheless, to the extent that they form an integral part of the end product that is in a competitive 
relationship with a product subject to discrimination, they may serve as an important factor in determining the presence of discrimination. Nevertheless, inputs are not directly assessed as part of the "likeness" test that considers physical properties and characteristics, consumer preferences, product end-uses, and tariff classification.

In the current dispute, the $\mathrm{AB}$ upheld the Panel's finding that the scope of the national treatment derogation must be the same as the scope of the national treatment obligation itself. It therefore focused on the examination of the "likeness" between the product purchased (electricity generated by solar cells and modules) and the product subject to discrimination (solar cells and modules), comparing them both as end products.

The AB did not evaluate whether PVCMs were inputs due to India's claims in appeal, which asked the $\mathrm{AB}$ to consider inputs beyond the "competitive relationship" test. In response, the AB highlighted that the consideration of inputs did not displace the criteria of a competitive relationship ( $\$ 5.24$ of $\mathrm{AB}$ report). Indeed, as a derogation to the national treatment obligation, it seems most reasonable that Article III.8(a) must share the same scope as the obligation itself, as the AB stated in Canada Renewable Energy ( $\$ 5.63$ of AB Report).

The $\mathrm{AB}$ thus missed the opportunity to take a strong stance on the consideration of inputs and processes of production. ${ }^{7}$ Given that the dispute raises questions on the WTO adjudicator's "objective assessment," the $\mathrm{AB}$ may be particularly wary of any perception about it overstepping its mandate. The $\mathrm{AB}$ did however recognize that the assessment of inputs can be relevant, in two respects: both to inform the evaluation of "likeness" and to determine the existence of discrimination ( $\$ 5.40$ of $\mathrm{AB}$ report). Such an acknowledgement might open a door for regulators to treat products differently depending on input's characteristics, potentially even beyond questions about Article III.8 derogations.

The second issue is an evaluation of India's core economic argument that India about the status of PVCMs as indispensable inputs for solar electricity production. A related issue is the United States' contention that PVCMs are not inputs at all.

This second set of questions is relatively straightforward to evaluate. Any reasonable economic definition would include solar cells and modules as production inputs for solar energy. For example, a neoclassical production function typically includes labor and capital. One might argue that PVCMs are not a variable input but instead are a fixed input, in particular, a piece of capital equipment. But from an economics standpoint, India's argument that without solar cells and modules there is no solar generated electricity would seem to be a sound one. One might imagine that technological advances may change how energy emitted from the sun is converted into useable electricity but under any current technical methods, solar cells (be they c-Si or thin film or concentrator cells) remain a central aspect of solar electrical power generation.

This analysis does not address whether it is economically efficient to allow for such a derogation but there are sound economic reasons for India to make this claim and few arguments in favor of the United States' position. For example, the NSM required all solar electricity generated under a power purchasing agreement to use Indian solar cells and modules beyond Phase II (i.e. post 2017). Technological advances abroad may not be available to Indian solar producers under such a domestic content requirement resulting in higher costs and/or lower productivity. The Indian approach certainly puts the Indian solar producers in a potentially precarious spot if domestic supplies were to become obsolete or subject to disruption themselves.

7 The debate about distinguishing between product and process for comparison of products has been long unsettled. For early literature on this debate, see Howse and Regan (2000) and Charnovitz (2002). The debate about the consideration of production methods has recently been raised in the context of the TBT Agreement, cf. US - Tuna (II) and EC - Seals cases (Conconi and Voon, 2016). 


\subsection{Criteria for Short Supply Exception}

We turn next to India's position that if the Article III derogation was found without merit, then an Article XX (j) exception for the DCR would apply.

As noted above, the AB had not previously interpreted Article XX (j) so that India-Solar Cells is especially important to clarify this exception's use.

This provision was originally envisaged "to permit, during the post-war transitional period, the use of differential internal taxes and internal mixing regulations as well as quantitative restrictions in order to distribute goods in short supply, to give effect to price controls based on shortages and to liquidate surplus stocks or uneconomic industries carried over from the war period." ${ }^{8}$ The drafters included the language even after the transitional post war period, envisaging situations such as natural disasters. ${ }^{9}$ The AB leaves open the possibility in India-Solar Cells that the short supply exception could be used beyond extreme cases of shortage due to wartime or natural disasters, as long as there is actual or imminent risk of shortage.

The $\mathrm{AB}$ described the legal standard applicable to the Article $\mathrm{XX}$ (j) exception based on established case law on other provisions of Article XX. It distinguishes the analysis of the measure itself from the analysis of the relationship between the measure and the pursued objective. If the former is not established, the $\mathrm{AB}$ argues there is no need to examine the latter.

\subsubsection{Measures Designed to Address Shortage}

The $\mathrm{AB}$ determined that a measure under Article XX (j) must be designed to address the acquisition or distribution of products in general or local short supply. This implies that there are products in short supply and that the measure is capable of addressing the acquisition or distribution of products in general or local short supply.

The AB makes the "availability" of products for purchase the key criteria in establishing the presence of products in short supply. It notes that this availability must be established on a case-bycase basis, but gives a list of elements that may be taken into account to determine the availability of supply. (See $\$ 5.71$ of AB Report.)

The AB determined that India did not sufficiently establish that there was a short supply of Indian PVCMs but it did recognize the possibility to consider the lack of manufacturing capacity and potential risks of disruption in estimating the existence of short supply. In particular, it considered that the lack of manufacturing capacity can lead to short supply but does not necessarily establish short supply as argued by India. The $\mathrm{AB}$ also held that potential risks of disruption may inform the consideration of short supply but do not amount alone to evidence towards actual disruptions to imports in PVCMs. An actual disruption in supply must still be established for Article XX (j) to be applicable. In particular, the text requires that the measures cease once "conditions giving rise to them have ceased to exist." This suggests that the short supply must be a current fact; arguments about possible shortages in the future seem to lie outside this general exception's scope.

Although the $A B$ rejected that a potential disruption in imports would justify the Indian DCR, it does consider that specific vulnerabilities to disruptions faced by developing countries should be taken into account for a short supply exception. Indeed, it notes that "different levels of economic development of Members may, depending on the circumstances, impact the availability of supply of a product in a given market" ( $\$ 5.72$ of $\mathrm{AB}$ Report). The $\mathrm{AB}$ therefore leaves space for broader applicability of the exception of short supply to developing countries.

8 Second Session of the Preparatory Committee of the United Nations Conference on Trade and Employment, Economic and Social Council, United Nations, E/PC/T/A/PV/30, 16 July 1947, at page 22.

See Mavroidis $(2012,355)$. 


\subsubsection{Relationship Between Measure and Pursued Objective: "Essential"}

A measure's relationship to a pursued policy objective is a crucial factor in analyzing a domestic regulation's WTO legality. The AB underlines that there is a distinction between exceptions that apply the criteria of "indispensable," "making a contribution to," or "necessary," inter alia. The AB recognizes that "weighing and balancing" different factors for the "essential" character of the measure may be different than for exceptions using the term "necessary." Nevertheless, the AB's balancing test for "essential" in India-Solar Cells is not fundamentally different from earlier assessments of "necessity." The $\mathrm{AB}$ does recall the requirement to apply the least restrictive alternative reasonably available applied in interpretations of Articles XX (a), (b) and (d). It mentions among the balancing factors a comparison of the measure at stake with reasonably available alternative measures but does not discuss less restrictive alternatives.

Having already rejected India's short supply argument, the AB missed the opportunity to analyze the relationship between the Indian DCR measure and its pursued objectives so did not clarify the meaning of "essential" as understood by Article XX (j).

\subsubsection{Economic Perspectives on India's Short Supply Argument}

The $\mathrm{AB}$ ruled that the lack of domestic manufacturing capability was not a sufficient argument for invoking the Article XX (j) short supply exception. When might such a "short supply" exception make economic sense? What does the data suggest about the broader vulnerabilities that India might face if it relied heavily on imported PVCMs?

One might imagine that WTO members might want to intervene in trade for a product for which market conditions are subject to various kinds of uncertainty. The essential question is what type of intervention would address the underlying risk with acceptable unintended consequences.

For example, a country might want to restrict exports of an essential food product or critical intermediate manufacturing input because of domestic or international market disruptions. Exporting a good in such circumstances would result in higher prices and potential difficulties for consumers. Economists would normally argue that higher prices would be an appropriate market signal to induce national or international firms to supply more to the domestic market. Indeed, this is an essential function of allocative efficiency associated with markets. Complete reliance on imports for an essential food or critical manufactured good might also suggest some type of intervention. But which intervention is most appropriate?

A threshold issue is whether there are any reasonable indications that international trade of PVCMs has been disrupted in the past or likely to be disrupted in the future. Without such a disruption, there are few reasons to insist on a domestic production presence to insure against possible supply problems.

One can look at three sets of data to evaluate whether there have been any recent disruptions in the market for solar cells and modules: 1) global production and trade patterns; 2) imports into India specifically; and 3) international prices. We will see below that recent trends point towards a growing market of PVCMs, increased trade, and falling prices, with little evidence of disruptions.

International Energy Agency data shows a dramatic increase in installed global solar electrical generation capacity in recent years from an estimated 0.6 gigawatts of capacity in 2000 to 5.6 gigawatts in 2006 to 303 gigawatts in 2016 (IEA, 2017). Perhaps most importantly, this installed capacity has increased in every year from 2000 to 2017.

Global trade data also suggest a relatively stable market for the photovoltaic cell industry. UN Comtrade (2017) data for Harmonized System code 854140 shows that between 2007 and 2016 global exports of PVCMs doubled from US\$23.2 billion to US $\$ 47.7$ billion. There was a drop in trade following 2011 but this was likely a result of the following effects: 1) the fall in fossil fuel prices; 2) reduction in domestic subsidies for solar energy such as feed-in-tariffs for countries such as Germany 
and Spain; 3) increased installation of domestic solar energy across the world, thereby diverting at least some supply to internal use; and 4) increased use of PVCM trade remedies that limit trade flows.

It is important to look at India's own experience with international trade in PVCMs. Figures 1 and 2 below are based on Indian government trade data, which do not correspond exactly to UN data since it is not reported on a calendar year basis. Figure 1 shows that Indian imports of photovoltaic cells have increased dramatically over the last decade. There was a drop that was coincident with the NSM becoming more restrictive in Phase I, Batch 2 in 2013 but imports have recently increased to unprecedented values, due mainly to imports from China. It is also important to remember that the DCRs applied only to projects involving SPDS selling to the Indian government; imports of PVCMs could enter India with no DCRs for all electricity not bought under government PPAs. Figure 2 shows that U.S. PVCM exports to India fell dramatically in 2013 and have not recovered. This reflects U.S. concerns about the impact of the DCRs but also reflects the reordering of this manufacturing sector by the rise of China.

Recent price data also belie concerns about any recent international trade disruptions. Figure 3 shows spot prices on crystalline modules in China and Germany, which are two benchmark markets for PVCMs. These falling prices reflect a number of economic factors. There are important economies of scale in solar cell production; high fixed costs are required to set up the production facilities. These high fixed costs are then spread across larger production runs so that average costs are falling. U.S. government reports suggest that lower prices for polysilicon ingots, a key component for the production of traditional solar cells and modules, fell by about 75 percent from early 2011 to 2013 and remained relatively flat since then (USITC, 2015). Finally, overcapacity likely has been encouraged by government direct or indirect subsidies for solar cell manufacturing. The effects of the subsidies themselves can possibly lead to countervailing duty cases if the resulting exports result in material injury to solar component manufacturers in importing countries. In addition, high fixed cost industries may continue to export at prices below average total costs in order to cover at least some of the fixed costs. Perhaps not surprisingly, there has been a market shakeout as many solar cell producers have declared bankruptcy across the world; overall global production has nevertheless continued to increase.

In short, there is strong evidence that the world solar cell and module industry has not been subject to global supply disruptions in recent years. From an economic standpoint, the AB made the correct decision in disallowing invocation of the short supply provisions of Article XX. Allowing India to avoid basic obligations such as national treatment based on such a slim reed of argumentation would be very problematic for the multilateral system. Indeed, the solar industry has been characterized, not by shortages, but instead by increased capacity and falling prices. Such price dynamics often lead to a plethora of trade remedy cases such as in the steel industry over the last few decades. In this sense, the PVCM manufacturing sector is following a standard pattern for high fixed costs industries that have become particularly favored by governments around the world and that are subject to trade remedy cases as the industries mature.

A potential approach would be for India to take this opportunity to import PVCMs at current low prices in order to expand sustainable electricity production across the country. This would have important advantages for India's stated goal of sustainable economic development to help lower poverty and with an eye towards climate change concerns. Indeed, the data discussed above suggests that India as a whole has seen a dramatic increase in solar cell imports even as it has tried to encourage a domestic solar manufacturing industry.

The analysis above certainly suggests that there have not been past disruptions in the solar sector. But there has been relatively little experience with a global market for this product so perhaps there might be some disruption in the future. What might constitute an "insurance" policy against such potential import supply shocks? Options might include: 1) trade restrictions; 2) stockpiling of the imported good; or 3) domestic production subsidies. All three could ensure domestic supply in times 
of disruptions but with varying degrees of economic disruption. The choice among these options can be guided by standard economic analysis of policy responses to managing risk.

Direct trade restrictions (e.g. antidumping and countervailing duties) can be imposed under WTO rules but only under certain circumstances. Safeguards are also possible but also are subject to WTO rules and dispute review. An important aspect of all of these types of cases is that "short supply" simply is not associated with their use. Instead, domestic governments need to show current (or threatened) damage done to a domestic industry because of too many imports and not problems associated with too little supply from foreign sources. In addition, one clear disadvantage to such import restriction policies is that they result in higher prices for the good in question.

It is interesting to note that the Indian Ministry of Finance declined to impose antidumping duties on imported solar cells and modules from China, the United States, Malaysia, and Taiwan in 2014 as recommended by the Indian Ministry of Commerce and Industry. Moreover, the very ambitious goals of the Indian government to increase the use of solar energy would be undercut by such duties, especially if there were insufficient domestic production capacity to meet the solar adoption targets. In addition, import restrictions would increase the costs of purchasing PVCMs for all consumers.

A less costly approach than imposing import restrictions to guard against future supply disruptions would be to stockpile solar cells and modules. There are no restrictions on stockpiling under GATT rules. Thus, India could pursue this policy without violating international trade obligations.

A useful analogy is to consider approaches in another energy source: petroleum. There certainly have been major disruptions in in petroleum markets in the past; such shocks could also occur in the future. For short-term disruptions, some countries have turned to emergency stocks, such as the U.S. Strategic Petroleum Reserve, which currently contains over 700 million barrels of oil (DOE, 2017). Petroleum has the advantage that it can be stored for long periods without degradation of the resource. Similarly, PVCMs would degrade only slowly over time and could be stored if there were real fears of a supply disruption. An Indian government truly worried about external trade shocks could certainly purchase large stocks of PVCMs, an approach particularly attractive given recent price developments in the relevant market.

Long-term disruptions lasting years present greater difficulties. Many governments have encouraged development of their own domestic energy sources (but generally without domestic content requirements) for long-term supply stability. The arguments for direct government encouragement of domestic production of solar cell and module are less compelling. Petroleum is consumed in the process of its use so that months-long disruptions can be very problematic. PVCMs on the other hand are capital equipment with a long effective life. A supply disruption would need to continue for many, many years before causing serious difficulties with current energy production capabilities. The long shelf life of solar equipment makes the political use of export embargoes much less dangerous, which in turn makes them less likely. Stockpiling over long periods does have the disadvantage that this is a field with likely rapidly changing technologies; stored solar cells and modules might become relatively obsolete albeit still usable with current production infrastructure.

From an economic perspective, domestic production subsidies for solar cells with no restrictions on imported sources also has important advantages. In a standard partial equilibrium setting, such subsidies would encourage domestic production but without the increase in prices associated with import restrictions. In addition, India's role as an important market in the global exports of solar cells could mean a reduction in world prices as Indian international purchases fell. Such a policy recommendation has two important downsides: 1) Indian government outlays would increase with such a policy; 2) Indian domestic subsidies that lowered world prices might be subject to international scrutiny. This latter issue is especially relevant given the lack of policy space for "green" subsidies under current international norms. 


\section{Climate Change Policies vs. Trade Obligations}

Solar electricity production has taken on greater urgency in recent years because of climate change fears. WTO disputes that involve an evaluation (and even condemnation) of domestic policies towards encouraging clean energy therefore are potentially very controversial. Indeed, there have been longstanding concerns about possible tensions between climate policies and multilateral trade rules including, for example, treating imports with higher carbon content differentially at the border. Some have argued that such carbon-intensive goods would not be "like" products with less carbon emitted during production; these "dirty" versions of the product would arguably not be subject to Article III non-discrimination. Others have noted that even if different products (or inputs) were subject to national treatment provisions of Article III, an Article XX environmental exception might be possible. ${ }^{10}$ In short, these arguments are analogous to those forwarded by India in the dispute discussed here.

But there are important differences. In the current dispute, India utilizes a particularly onerous policy (eventual outright prohibition of foreign inputs for solar electricity purchased by the government) and invokes GATT provisions that are not directly about environmental protection. Although the $\mathrm{AB}$ rejected India's arguments, the ruling leaves open the possibility to use these provisions to justify climate change policies in the future.

Article XX exceptions leave Members autonomy to define their own public policy objectives as long as they do not abuse their prerogative and do not use them as disguised protectionist actions. Earlier cases have been examined under the provisions of protecting health (GATT Article XX (b)) and the protection of exhaustible natural resources (GATT Article (XX (g)), including endangered species. ${ }^{11}$ In contrast, India's argument in India - Solar Cells invokes GATT Articles XX (j) and XX (d), i.e. "short supply," and "compliance with laws and regulations" that could be used to justify a broad range of policy objectives, including measures pursuing environmental protection.

\section{GATT Article XX (j): Short Supply Exception for Renewable Energy Goods}

As discussed above, Article XX (j) justifies domestic measures otherwise inconsistent with WTO obligations if they are essential to address a situation of short supply. It is in the context of looking at the nexus between the trade-restrictive measure and the objective pursued that the $A B$ takes into account "the relative importance of the societal interests or values that the measure is intended to protect" ( $\$ 5.59$ of AB Report). Nothing in the AB's reasoning in the current dispute explicitly referred to the protection of supply of renewable energy as a "vital" social objective." 12 The weighing and balancing test of Article $\mathrm{XX}$ could be an avenue for the $\mathrm{AB}$ to recognize the vital character of addressing climate change in the future, provided that the parties raise this argument explicitly in a way that India did not in its argumentation.

However, India's argument that "insufficient" domestic production of a renewable energy input was grounds for invoking a general exception under Article XX is highly suspect. For example, there are many less intrusive methods to help increase the use of renewable energy that fall far short of discriminating against foreign suppliers. India's overly broad appeal to global climate commitments undercut the possible appropriate use of Article XX (j). One might easily imagine many countries

10 See for example Bhagwati and Mavroidis (2007), Brainard and Sorkin (2009), Charnovitz and Fischer (2015), Green (2005), Houser, T., et al. (2009), Hufbauer, et al. (2009), Mattoo, A., et al. (2009) Moore (2010 and 2016).

11 For an overview of the case law raising environmental objectives in Article XX exceptions, see (Trebilcock, et al. 2013, 664)

12 Previous case law on "necessity" has established that "The more vital or important those common interests or values are, the easier it would be to accept as "necessary" a measure designed as an enforcement instrument. See $\$ 1162$ of KoreaBeef. 
abusing such an exception; simply invoking a laudable national priority (e.g. poverty reduction, regional economic development, battling unemployment) combined with "insufficient" domestic production surely would not be a recipe for a sustainable non-discriminatory multilateral trading system. The AB's rejection of India's arguments on GATT Article XX (j) was therefore important to prevent such future abuses.

\section{Article XX (d): Environmental Obligations as a "Laws and Regulations" Exception}

In allowing Members to justify their WTO-inconsistent measures to compliance with other "laws and regulations," Article XX (d) could potentially provide coherence between WTO Members obligations under the WTO and in other fora. AB consideration of international environmental obligations through this exception could arguably allow for a better balance between trade and environment priorities.

The WTO adjudicator's position with regards to non-WTO obligations has long been uncertain (Mavroidis, 2012, 342). Article XX (d) was interpreted narrowly by Panels in the GATT era (c.f. Japan - Agricultural Products I; and EEC - Parts and Components), and the AB confirmed a narrow approach by excluding international obligations from the scope of the article ${ }^{13}$ (Mavroidis, 2016, 442 et seq.). In the current case, the $\mathrm{AB}$ seems to acknowledge the possibility that non-WTO international obligations could justify domestic regulations under Article XX (d), without applying it to the current case. Doubt therefore remains as to the exception's applicability to international instruments in the future.

The AB recalled its Mexico - Soft Drinks position noting that "laws and regulations" cover only rules that form part of the domestic legal system. However, it goes further into explaining the rationale for excluding international obligations from the scope of "laws and regulations" by relying on the ordinary meaning of these terms, which essentially refer to domestic laws and regulations, as was suggested by Davey and Sapir (2009). In addition, the AB makes a timid step towards considering international obligations under the scope of Article XX (d) by highlighting the variety of means by which they can form part of the domestic legal system. It underlines that international agreements can "form part of the domestic legal system of a Member in at least two ways" (emphasis added, at $\$ 5.140$ of $\mathrm{AB}$ report). This covers agreements that have been incorporated into a domestic legal system or that have a "direct effect" within the domestic system. The AB added that "... there may well be other ways in which international instruments or rules can become part of that domestic legal system." The $\mathrm{AB}$ therefore concluded that only a case-by-case analysis could determine whether international instruments form part of the domestic legal system, and most importantly that this analysis must be complemented by the same test for normativity and specificity of the rules at stake as it applies to domestic "laws and regulations." Although these criteria may resemble those used in some legal systems to determine direct effect or the "self-executing" nature of international instruments (Klabbers, 2017, 323-324), they do offer more objective guidance for Panels in considering laws and regulations for the purpose of article $\mathrm{XX}(\mathrm{d})$.

By imposing this case-by-case consideration of the normativity and specificity factors, the $\mathrm{AB}$ applies clearer criteria to identify the scope of laws and regulations: the domestic or international source of the instrument no longer appears as the determining factor. It therefore seems that if obligations contained in international instruments fulfill these factors and are part of the domestic legal system, they would be covered by the exception of Article XX (d). This would be the case particularly in "monist" legal systems - i.e. in which treaties become part of domestic law after they have been concluded in accordance with the constitution, without legislation (Aust, 2007, 183).

Focusing on India's claims on direct effect, the AB did not conduct as thorough an examination of the international instruments as it did for the domestic instruments. However, the obligations on which

13 Mexico - Soft Drinks, $\$ 8.162$ et seq. 
India based its arguments were mainly broad objectives of sustainable development goals as well as commitments to adopt national and regional policies to mitigate climate change and address greenhouse gas emissions ( $\$ 7.272$ of $\mathrm{AB}$ report). The $\mathrm{AB}$ found that these do not seem to satisfy the "specificity" requirement set by the $\mathrm{AB}$ to describe "laws or regulations." The $\mathrm{AB}$ saw these international instruments as more "aspirational" than "specific," failing to comply with the AB's standard of review set for Article XX (d). It is therefore very likely that even if the AB had conducted a more thorough analysis of the content of the instruments cited by India, it would have excluded them from the scope of the exception.

There are also serious questions about whether an Article XX (d) exception would have helped India attain its primary policies. Recall that there are three distinct policy goals that India claims to be pursuing: 1) eradicating poverty by broadening the availability of electricity; 2) meeting international climate change commitments to reduce carbon emissions; and 3) expanding domestic production of solar energy manufacturing. Each of these issues arguably reflects various market externalities. The DCRs could help meet the third goal but would undercut the other two policy objectives by raising the price of solar cells and modules. The Appellate Body's role is not to assess whether or not India's goals are appropriate. In this particular instance, adhering to established multilateral rules of nondiscrimination likely would be helpful to India accomplishing the first two objectives. And given that India's own National Action Plan on Climate Change noted above claims that the Indian government's "overriding priority" is poverty eradication, the Appellate Body's position not to allow this specific Article XX exception seems particularly fortuitous.

\section{Conclusion}

The rapid expansion of the number of renewable energy WTO disputes calls for a clear position of the $\mathrm{AB}$ with regard to climate change to ensure predictability of trade in renewable energy products in particular, as noted by Marhold (2013). The AB report in India - Solar cells did not offer an innovative position in this regard. Its reasoning on general exceptions under Article XX (j) and (d) does seem to open some possibilities for justifying environmental policies in the future, albeit very cautiously. The AB confirms that only domestic laws and regulations are covered by Article XX (d) but underlines that international obligations may form part of the domestic legal order in a variety of ways. Environmental policies essential to address short supply in renewable energy products may also be justified under Article XX (j). However, given that this reasoning is not applied to the current case, it is difficult to be certain about its application in the future.

As mentioned in the introduction, India raised a dispute against the state-level domestic content requirements in the U.S. after lengthy discussions in the Subsidies and Countervailing Measures Committees. ${ }^{14}$ This could be because there is a tit-for-tat dispute between the two countries, which did not get solved by the WTO adjudicator's reports and may therefore likely continue in various fora. It could also suggest that there are issues regarding renewable energy and WTO obligations that remain unsolved, such as how WTO Members could best incentivize the use of renewable energy by domestic producers without violating their WTO obligations. Both explanations could apply. Either way, additional Panel and AB's elucidation of relevant WTO obligations in US -Renewable Energy Sector will be very welcome.

More traditional trade issues are also at play in this dispute. India's argument that it should be able to invoke a "short supply" Article XX exception to justify a domestic content restriction simply on the basis of an "inadequate" domestic manufacturing capacity is quite problematic. The AB also soundly rejected India's contention that a government can discriminate against foreign firms in upstream

14 See India's initial questions to US notifications in G/SCM/Q2/USA/59, and subsequently the Committee discussions in April 2013 (G/SCM/M/85) and October 2013 (G/SCM/M/87), April 2014 (G/SCM/M/89), October 2014 (G/SCM/M/91), April 2015 (G/SCM/M/93). 
industries that supply inputs into a public procurement project. Ruling in India's favor would have opened many opportunities for governments to force a myriad of suppliers to buy domestically as long as the government purchased the final good.

India's desire to use policy to address critical social goals such as poverty reduction, expansion of access to electricity, reducing greenhouse gases, and encouraging a domestic solar energy manufacturing sector is of course understandable. But effective policy development usually means prioritizing goals and understanding interactions among those objectives. In this context, this would mean recognizing that actions such as banning foreign sourcing of solar cells and modules can seriously undercut other important policy aims. One might for example argue that spreading electricity access to rural populations and adopting solar energy in India, with its abundant sunshine, would be better served by subsidizing installation of solar panels from any source. In addition, the jobs and value-added associated with installation and maintenance of solar energy capacity likely are greater than the domestic production of solar cells themselves, a point noted in a 2012 National Resources Defense Council study (NRDC, 2012) on India's national solar project. In short, India may need to evaluate whether achieving one goal (increasing employment for a narrow range of manufacturing activities) may undercut what the Indian government may deem even more important (electrification of rural areas, reducing poverty, and combating climate change).

Even if India deems the expansion of solar energy manufacturing to be a critical long-term domestic policy goal, the WTO system relies on non-discrimination-unless there are compelling reasons to relax this core obligation. India simply did not make a convincing argument that domestic content rules for an upstream input were justified in this case. The Appellate Body was quite correct in rejecting its claims. 


\section{References}

Aust (2007), Modern Treaty Law and Practice, Cambridge: Cambridge University Press.

Bhagwati, Jagdish and Petros Mavroidis (2007), 'Is action against US exports for failure to sign Kyoto Protocol WTO-legal?', World Trade Review, 6(2): 299-310.

Brainard, Lael. and I. Sorkin, (eds.) (2009). Climate Change, Trade and Competitiveness: Is A Collision Inevitable? Washington DC: Brookings Trade Forum.

Bown, Chad P. (2016), 'Global Antidumping Database,' The World Bank, http://econ.worldbank.org/ttbd/gad/ (accessed 1 May 2017).

Chang, Seung Wha (2016), 'Farewell Speech of Seung Wha CHANG at the DSB.' https://tinyurl.com/yb94p383 (accessed 6 July 2017)

Charnovitz, Steve. (2002), 'The Law of Environmental 'PPMs' in the WTO: Debunking the Myth of Illegality.' Yale Journal of International Law 27 (1).

Charnovitz, Steve, and Carolyn Fischer (2015). 'Canada-Renewable Energy: Implications for WTO Law on Green and Not-So-Green Subsidies.' World Trade Review 14 (2): 177-210.

Conconi, Paola, and Tania Voon. (2016), 'EC-Seal Products: The Tension between Public Morals and International Trade Agreements.' World Trade Review 15 (2): 211-34.

Davey and Sapir (2009), 'The Soft Drinks Case: The WTO and Regional Agreements', World Trade Review 8(1): 5-23

DOE (2017), 'Strategic Petroleum Reserve', United States Department of Energy, https://tinyurl.com/y8vbmfx8 (accessed 11 May 2017).

Flett, James (2010), 'Collective Intelligence and the Possibility of Dissent: Anonymous Individual Opinions in WTO Jurisprudence.' Journal of International Economic Law 13 (2): 287-320.

Government of India (2008), 'National Action Plan on Climate Change', June 30, 2008, https://tinyurl.com/ybnjul5z (accessed 16 July 2017).

Green, Andres (2005). 'Climate Change, Regulatory Policy and the WTO: How Constraining Are Trade Rules?', 8 Journal of International Economic Law 143.

Houser, T., R. Bradley, B. Childs, J. Werksman, and R. Heilmay (2009), Leveling the Carbon Playing Field (Washington DC: Peterson Institute for International Economic Policy).

Howse, Robert, and Donald Regan (2000), 'The Product/Process Distinction - An Illusory Basis for Disciplining 'Unilateralism' in Trade Policy.' European Journal of International Law 11 (2): 24989.

Hufbauer, Gary Clyde, Steve Charnovitz, and Jisun Kim (2009). Global Warming and the World Trading System, New York: Columbia University Press.

IEA (2016), 'Snapshot of Global Photovoltaic Markets,' International Energy Agency, Report IEA PVPS T1-31:2017, http://www.iea-pvps.org/ (accessed 30 June 2017).

Klabbers, J. (2017), International Law, Cambridge: Cambridge University Press.

Lewis, Meredith Kolsky (2012), 'Dissent as Dialectic: Horizontal and Vertical Disagreement in WTO Dispute Settlement.' Stanford Journal of International Law 48 (1).

Marhold, Anna (2013), 'The World Trade Organization and Energy: Fuel for Debate.' ESIL Reflections 2 (8). 
Mattoo, A., A. Subramanian, D. van der Mensbrugghe, and J. He (2009), 'Reconciling Climate Change and Trade Policy', Peterson Institute for International Economic Policy Working Paper 09-15.

Mavroidis, Petros (2012), Trade in Goods. Oxford: Oxford University Press.

Mavroidis, Petros (2016), The Regulation of International Trade, Volume 1, Cambridge: MIT Press.

Moore, Michael O. (2016), 'Carbon Safeguard? Managing the Friction Between Climate Policy and Trade Policy,' Journal of World Trade 51(1): 43-66.

Moore, Michael O. (2010), 'Implementing Carbon Tariffs: A Fool's Errand?' World Economy 34(10), 1679-1702.

NRDC (2012), 'Laying the Foundation for a Bright Future: Assessing Progress Under Phase 1 of India's National Solar Mission', National Resources Defense Council http://tinyurl.com/ydfkbtfo (accessed July 3, 2017).

Rubini, Luca (2014), 'The Good, the Bad, and the Ugly': Lessons on Methodology in Legal Analysis from the Recent WTO Litigation on Renewable Energy Subsidies.' Journal of World Trade 48 (5): 895-938.

Rubini, Luca, and Aaron Cosbey (2017), 'E15 Initiative | Does It FIT? An Assessment of the Effectiveness of Renewable Energy Measures and of the Implications of the Canada - Renewable Energy/FIT Disputes.' E15 Initiative. https://tinyurl.com/n6la6xc (accessed 6 July 2017).

Trebilcock, M. J., Robert Howse, and Antonia Eliason. (2013), The Regulation of International Trade. Fourth edition. Abingdon: Oxon Publishing; New York: Routledge.

UN Comtrade (2017), United Nations Comtrade Database, https://comtrade.un.org/ (accessed 30 May 2017).

USITC (2015), 'Certain Crystalline Silicon Photovoltaic Products from China and Taiwan' U.S. International Trade Commission, Publication 4519. Page V-1, https://tinyurl.com/y8slf6e3 (accessed 6 July 2017).

USTR (2013), 'United States Challenges India's Restrictions on U.S. Solar Exports.”'United States Trade Representative, https://tinyurl.com/yamrn7dp (accessed 6 July 2017).

WTO (2016), Statement by the United States at the Meeting of the WTO Dispute Settlement Body, Geneva, May 23, 2016, https://tinyurl.com/yaerv87u (accessed 19 July 2017) 
Figure 1: Indian Photovoltaic Imports

(HS 854140)

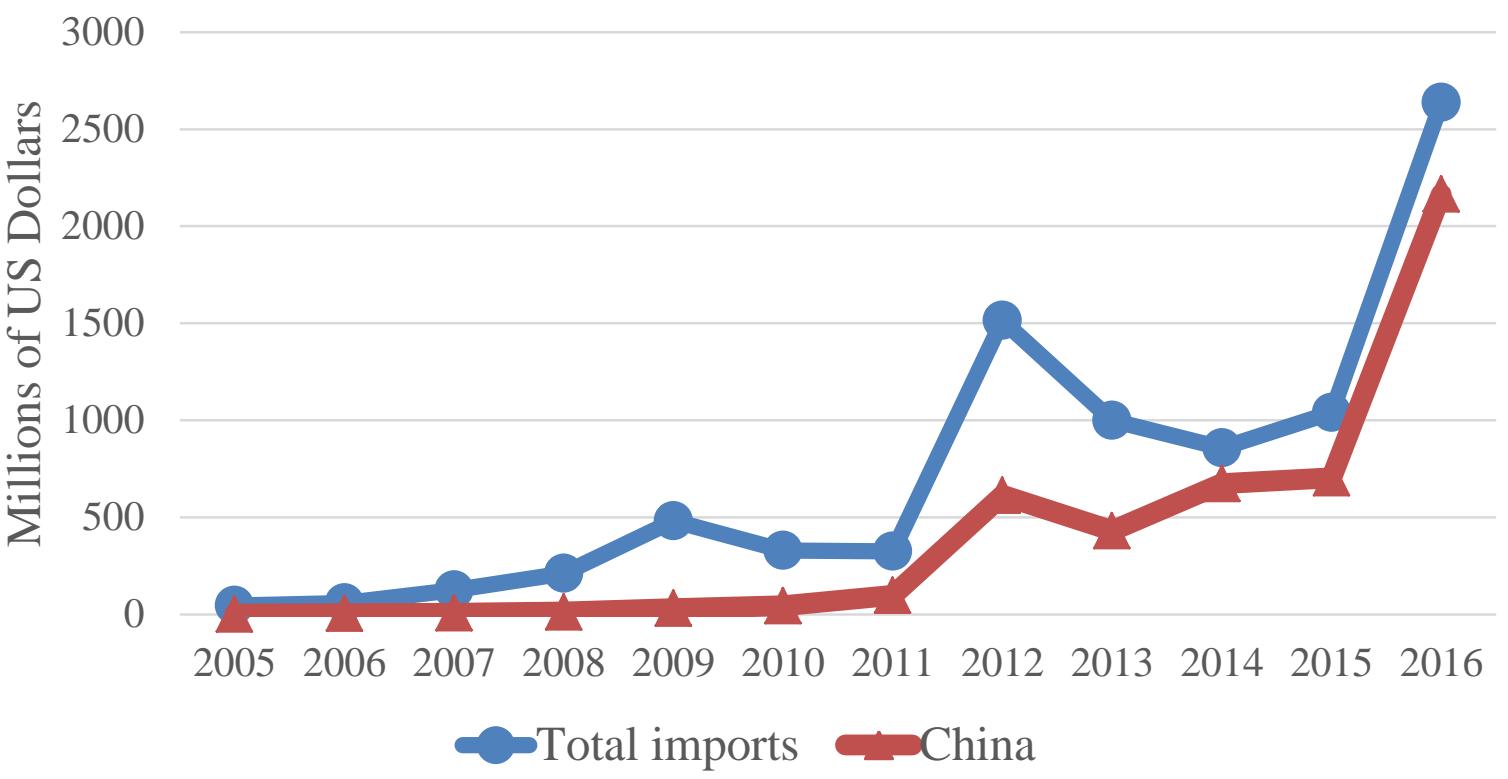

Source: Indian Ministry of Commerce and Industry

Figure 2: Indian Photovoltaic Imports

from USA

(HS 854140)

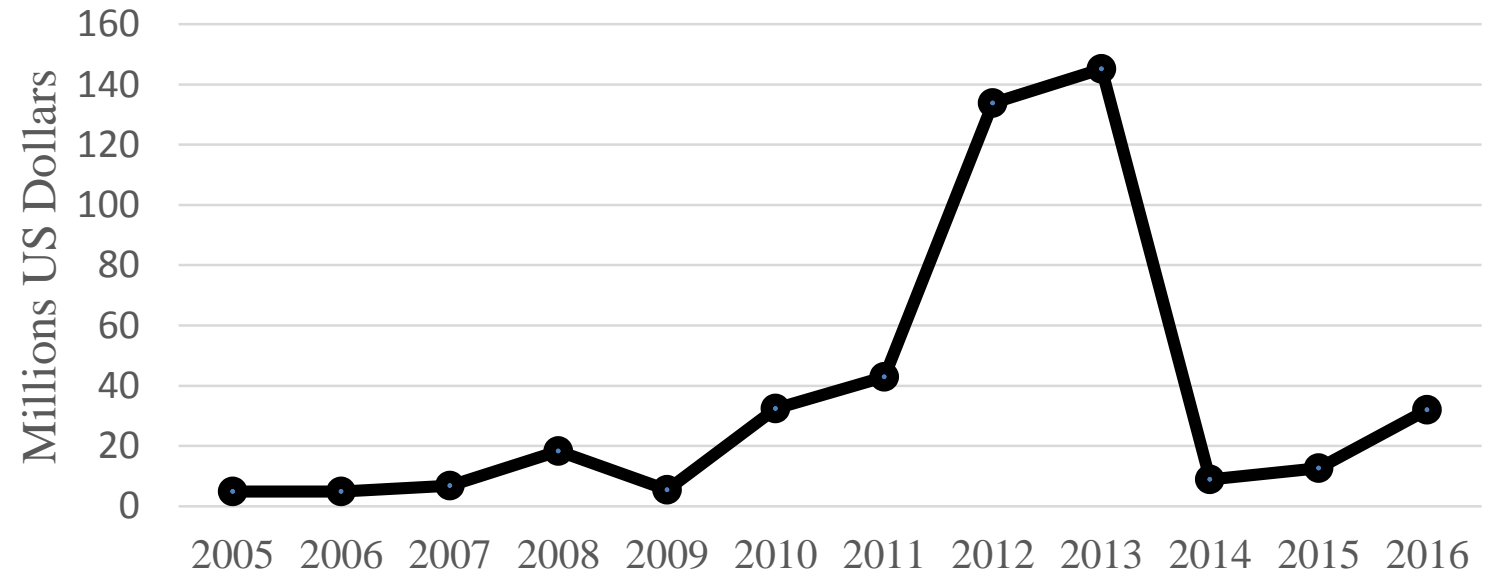

Source: Indian Ministry of Commerce and Industry 
India - Solar Cells: Trade Rules, Climate Policy, and Sustainable Development Goals

\section{Figure 3: Crystalline Photovoltaic Module Spot Prices}

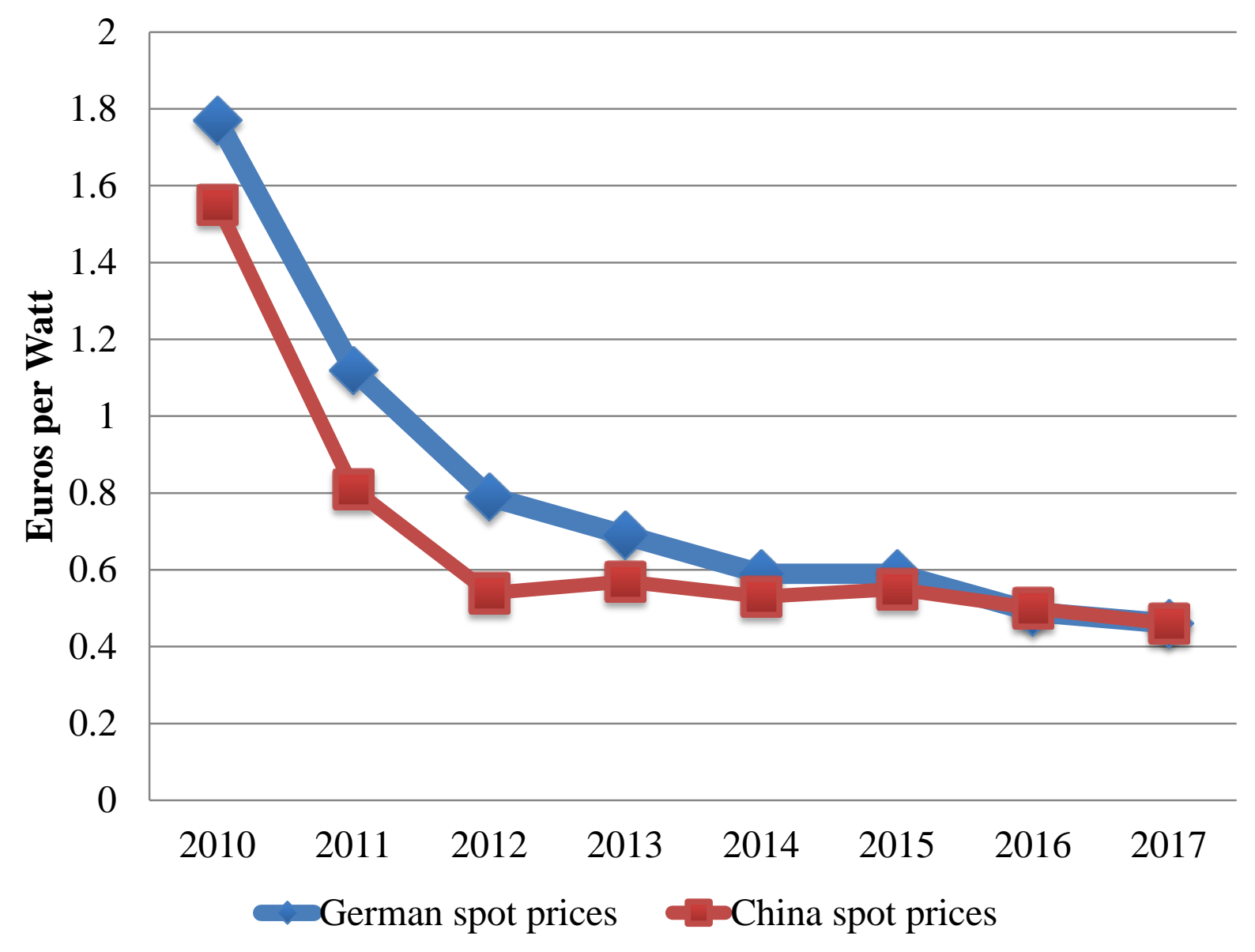

Source: http://pvwchange.com (accessed 20 May 2017) 


\section{Author contacts:}

\section{Marianna Karttunen}

Regulatory Policy Division, OECD

2 rue André Pascal

75016 Paris

France

Email: Marianna.karttunen@oecd.org

\section{Michael O. Moore}

Department of Economics and Elliott School

Institute for International Economic Policy

1957 E St., Suite 502

George Washington University

Washington DC 20052

Email: mom@gwu.edu 